\title{
IMPACTS OF HOLOCENE PERTURBATIONS OF THE ONEGA-LADOGA HYDROLOGICAL SYSTEM ON THE ANCIENT COASTAL POPULATION
}

(C) 2017

\author{
Nikonov Andrei Alekseevich, doctor of geological and mineralogical sciences, \\ chief researcher of Seismic Hazard Laboratory \\ Schmidt Institute of Physics of the Earth of Russian Academy of Sciences (Moscow, Russian Federation)
}

\begin{abstract}
Neolithic settlers of the periphery area of the Last Glaciation were affected during the Holocene by dramatic sequences of the catastrophic environmental transformations. This statement is developed in the paper based on geodynamic approach which is important to understand factors of social-cultural development of those territories. The paper contains results of the investigations of environmental cataclysms in the Onega-Ladoga hydrosystem during the last $7 \mathrm{ca}$. Three major paroxysms $(5,7,5,3,3,1 \mathrm{BP})$ have been identified basing on stratigraphical and spatial analyses of the reference archaeological and palaeogeographical studies of the Vuoksa, Svir' and Neva rivers. In each of the mentioned case large earthquake had resulted in drastic water cataclysms. Environment and hydrological regime of the main water basins were chanced and these perturbations stipulated disastrous consequences for lives, livelihoods and migrations of on-shore Neolithic communities.

Keywords: man and environments; Neolithic; factors of social-cultural changes; geoarchaeology; hydrographic pattern transformation; Ladoga transgression; earthquakes; tsunami; outlet canals; subsistence of Neolithic communities; Onega Lake; Ladoga Lake; Vuoksa river; Svir river; Neva river.
\end{abstract}

УДК 902

Статья поступила в редакцию 12.06.2017

\section{ФОРМИРОВАНИЕ СОЦИАЛЬНО-КУЛЬТУРНЫХ ОБЩНОСТЕЙ В РЕГИОНЕ ФИНСКОГО ЗАЛИВА В УСЛОВИЯХ ПРИРОДНЫХ ИЗМЕНЕНИЙ РАННЕГО - СРЕДНЕГО ГОЛОЦЕНА}

(C) 2017

Герасимов Дмитрий Владимирович, кандидат исторических наук, научный сотрудник отдела археологии Музей антропологии и этнографии им. Петра Великого (Кунсткамера) РАН

(2. Санкт-Петербург, Российская Федерачия)

Холкина Маргарита Алексеевна, научный сотрудник

Научно-исследовательский ичентр «Актуальная археология» (г. Санкт-Петербург, Российская Федерациия)

Аннотащия. Археологические материалы каменного века восточной части региона Финского залива свидетельствуют о существовании здесь с периода позднего мезолита и до конца неолита устойчивой границы между культурными ареалами. Различия между ними проявляются в определенных категориях инвентаря прежде всего в керамике (сперрингс и нарвская, керамические типы позднего неолита), а также в украшениях и искусстве малых форм. Граница сохраняется на протяжении тысячелетий, несмотря на происходившие за это время существенные изменения в облике материальной культуры населения региона. Возникновение этой границы предположительно могло произойти в позднем мезолите, в 7 - середине 6 тыс. до н.э. Гипотетически оно могло быть связано с появлением нового населения и, возможно, климатическим событием «8200 л.н.». Граница представлена в археологических материалах до массового проникновения в регион носителей культуры шнуровой керамики на рубеже 4 и 3 тыс. до н.э. Феномен культуры типичной гребенчатоямочной керамики, существовавший в регионе с конца 5 до второй половины 4 тыс. до н.э., предположительно, появился не в результате смены населения, а как проявление интеграции населения под влиянием внешних (социокультурных?) факторов.

Ключевые слова: Финский залив; Приладожье; археология; археологическая культура; миграции; поздний мезолит; неолит; керамика сперрингс; нарвская; типичная гребенчато-ямочная; ускела; асбестовая керамика; поздняя гребенчато-ямочная; шнуровая; социальные связи; культурные ареалы; граница; социальнокультурные общности.

Процессы формирования социально-культурных общностей являются одной из центральных проблем культурной антропологии в целом. Разработка моделей таких процессов имеет большое значение как для изучения исторического развития человечества, так и для понимания современных социокультурных процессов. Социология, этнография и изучение письменных исторических источников позволяют изучать развитие общества и культуры значительно полнее и подробнее, нежели археология. Однако возможности этих наук ограничены хронологическими рамками доступности источников, что существенно затрудняет изучение процессов формирования и трансформа- ций социокультурных общностей в долговременной перспективе - возможности проследить на этнографическом материале возникновение таких общностей достаточно редки (напр.: [1]). Археологическая наука, при всей ограниченности источников (ср.: [2]), позволяет изучать социокультурные процессы, в том числе формирование социокультурных общностей, на значительных временных промежутках.

Вопрос о соотношении этноса и (археологической) культуры и непосредственно связанное с ним противостояние миграционной и диффузионной теорий в интерпретации наблюдаемых по археологическим данным культурных изменений уже более сто- 
летия являются одними из наиболее обсуждаемых, и при том остающимися нерешёнными проблем археологии. В недавнее время интерес к этим проблемам вновь обострился в связи с полученными результатами палеогенетических исследований (подробный обзор вопроса см.: [3]).

Накопленные к настоящему времени данные по археологии региона Финского залива позволяют предположить здесь существование в восточной части региона границы между двумя крупными культурными ареалами, сохранявшей стабильность на протяжении большей части каменного века, несмотря на происходившие за несколько тысячелетий весьма существенные изменения в культуре. После завершения ледникового периода рассматриваемая территория вместе с Восточной Фенноскандией оставалась последней (за исключением арктических областей) не освоенной человеком значительной по площади частью Европы. Освоение этих регионов человеком происходило, в сравнении с другими частями ойкумены, относительно недавно, благодаря чему объем и разнообразие археологических свидетельств происходивших здесь социокультурных процессов значительно богаче, чем для аналогичных процессов в более ранние периоды времени на других территориях. В то же время, в отличие от других территорий, для рассматриваемого региона можно исключить из числа факторов, влияющих на развитие культуры, взаимодействие аборигенного и пришлого населения, по крайней мере, для ранних этапов освоения. Всё указанное позволяет рассматривать изучение формирования культурных ареалов в регионе Финского залива в каменном веке как редкую возможность создания на археологическом материале достаточно обоснованной и подробной модели процесса формирования социокультурных общностей в древности.

Восточная Фенноскандия и восточная часть региона Финского залива стали доступны для заселения после отхода ледника и освобождения от вод Балтийского ледникового озера во второй половине 10 тыс. до н.э. И хотя с этого времени фиксируется проникновение отдельных небольших охотничьих коллективов в глубь Фенноскандии [4], несомненные следы присутствия здесь человека фиксируются только в середине IX тыс. до н.э. Освоение данной территории связано со временем распространения в регионе бореальных лесов, совпадающим с трансгрессивной фазой Анцилового озера [5-7]. Ландшафтная приуроченность и фаунистические материалы раннемезолитических комплексов свидетельствуют о том, что территория заселялась охотниками-собирателями, ориентированными на эксплуатацию ресурсов лесной экологической ниши [6; 7]. Археологические материалы дают все основания полагать, что не было определенной территории, откуда происходило заселение освободившихся пространств. Регион осваивался коллективами с южных и юго-восточных территорий, продвигавшимися вслед за распространением привычной экологической ниши [7]. В то же время имеются веские основания предполагать существование развитой системы устойчивых коммуникаций в пределах всей лесной зоны Восточной Европы и Зауралья, включая и рассматриваемую территорию. Свидетельствами тому являются находки весьма схожих типологически и технологически изделий из кремня, кости, комбинированных орудий в удаленных друг от друга ранне- мезолитических контекстах [8-10], предметов из каменного сырья, источники которого расположены в нескольких сотнях километров от места находки.

На протяжении раннего мезолита - времени освоения региона Финского залива - происходит стремительная трансформация каменной индустрии, обусловленная, прежде всего, переходом на использование местного сырья - кварца и сланца. Однако в материалах археологических памятников, датируемых, как минимум, до середины 8 тыс. до н.э., сохраняются черты, характеризующие период раннего мезолита этой территории - стремление к использованию наиболее качественного из доступного каменного сырья, наличие крупных типологически выраженных форм, присутствие пластинчатого компонента. Во всех раннемезолитических комплексах присутствуют, хотя бы и в небольшом количестве, артефакты из импортного кремня, свидетельства использования технологии получения пластин и микропластин [5; 10-14].

В целом, можно заключить, что регион на раннем этапе освоения представлял собой единое в культурном отношении пространство. Социальные коммуникации как внутри рассматриваемой территории, так и с сопредельными регионами, вероятно, были основаны на достаточно высокой степени подвижности населения в пределах значительных ареалов. Это позволяет предположить и определенную общность населения.

Существенные изменения в культуре населения региона Финского залива начинают наблюдаться со второй половины 8 тыс. до н.э. Прослеживается переориентация каменных индустрий на максимальное использование наиболее легкодоступного локального сырья. Резкое, по сравнению даже с концом периода раннего мезолита, уменьшение доли изделий из импортного кремня и доминирование биполярной технологии расщепления, ориентированной на максимально эффективное использование низкокачественного но легкодоступного сырья, возможно, свидетельствует об исчезновении существовавшей в раннем мезолите развитой и устойчивой системы межрегиональных коммуникаций [15].

В это время начинается хозяйственное освоение морского побережья и островов, о чем свидетельствует расположение поселений [7]. Формируется комбинированная присваивающая система жизнеобеспечения, совмещающая эксплуатацию ресурсов леса, внутренних водоемов и морского побережья. Добыча ластоногих постепенно становится одной из важнейших составляющих системы жизнеобеспечения для населения побережья Балтики и крупных пресноводных водоемов, где нерпа образовала особые популяции - Ладоги, Древней Саймы и, вероятно, Онеги [16-18]. Указанные изменения в материальной культуре, системах расселения, жизнеобеспечения и социальных коммуникаций свидетельствуют об обоснованности выделения позднего мезолита в отдельный период социокультурного развития рассматриваемой территории [13].

Посуда из обожженной глины распространяется на рассматриваемой территории практически одновременно во второй половине 6 тыс. до н.э. в виде двух традиций - нарвской и сперрингс, разительно различающихся между собой по технологии изготовления, орнаментации и форме сосудов [19-21]. В принятой в России системе археологической периодизации появление керамики маркирует начало эпо- 
хи неолита. В то же время, многократно отмечалось, что для значительной части населения лесной полосы Восточной Европы освоение керамики не сопровождалось иными существенными изменениями в материальной культуре, в системе расселения и жизнеобеспечения. Это по большей части справедливо и для носителей традиций керамики сперрингс и нарвской, что дает основания исследователям, преимущественно из стран Европы, относить эти культуры к позднему мезолиту (напр.: [22; 23]. В настоящей работе предпринята попытка обосновать наличие в восточной части региона Финского залива устойчивой границы культурных ареалов, существовавшей в каменном веке на протяжении нескольких тысячелетий, обозначить предполагаемые хронологические рамки этого феномена и рассмотреть некоторые возможные факторы, влиявшие на его развитие.
В настоящее время на территории Южной Финляндии, Карельского перешейка и Южного Приладожья известно несколько сотен археологических комплексов с керамикой типа сперрингс. Ареал распространения этой керамики продолжается далеко на восток, в Карелию и Вологодскую область. Выделяются локальные вариации в керамической традиции [24]. В целом, однако, керамика типа сперрингс имеет характерные черты, отличающие ее от типов, представленных одновременно на других территориях и от сменившей ее типичной гребенчато-ямочной керамики (ТГК). Это толстостенная (до 1,2-1,4 см) керамика с примесью крупной дресвы, слабопрофилированная, с уплощенным срезом венчика (рис. 1). Орнамент представлен прочерченными линиями, ямками, отпечатками гладкого и крупного гребенчатого штампа.

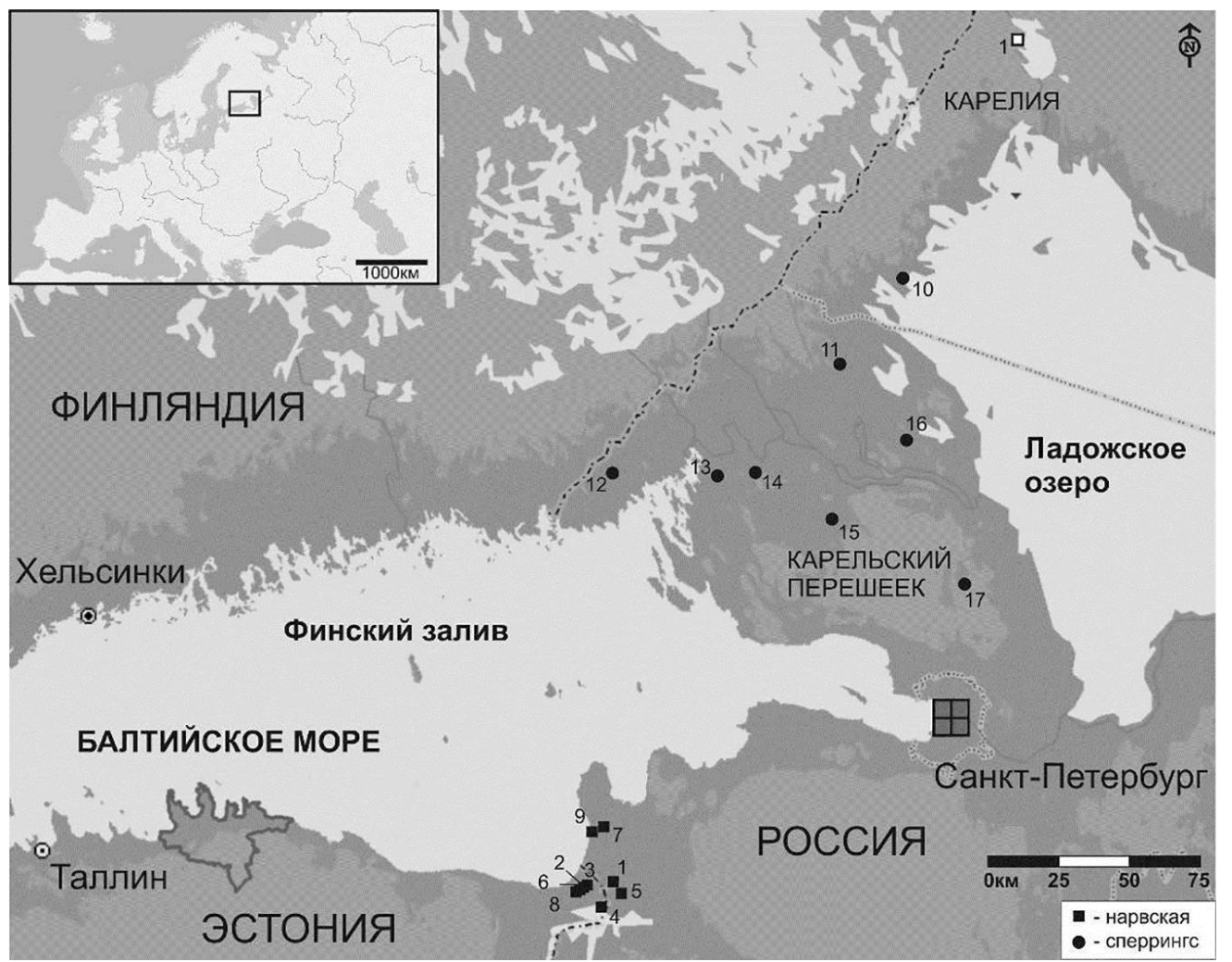

Рисунок 1 - Карта опорных комплексов с ранненеолитической керамикой в восточной части региона Финского залива. Памятники с нарвской керамикой: 1 - Извоз 2; 2- Рийгикюла VI; 3- Рийгикюла IV; 4- Нарва Йоарг (слой 1); 5- Ломми III; 6- Рийгикюла IX; 7-Галик 3; 8- Рийгикюла XII; 9- Кузёмкино 1-5. Памятники с керамикой сперрингс: 10 - Куркиёки 33; 11 - Большое Заветное 4; 12 - Холмогорское 1; 13 - Светлое $1 ; 14$ - Вещево 1; 15-Силино 1; 16- Комсомольское 3; 17-Хепо-Ярви

Датировки из контекстов с керамикой сперрингс с территории Карелии и Карельского перешейка [2528] указывают на распространение этого типа керамики во второй половине 6 тыс. до н.э. Судя по имеющимся радиоуглеродным датам [29; 30; 22], ровно в то же время на южном побережье Финского залива, в Прибалтике и Белоруссии распространяется керамика нарвской традиции, весьма отличающаяся от керамики типа сперрингс. Она менее толстостенна, содержит примесь раковины и измельченных растений, лепилась из узких лент характерным приемом «встык» (так называемый U-тип стыковки лент), покрыта расчесами, гребенчатыми вдавлениями, наколами (рис. 2) [31; 22]. Прослеживаются локальные различия внутри ареала распространения нарвской керамики (напр.: [29]).

Ареалы распространения этих двух керамических традиций не перекрываются (рис. 3). По мнению
В.И. Тимофеева [32], в материалах стоянки Березье в низовьях р. Волхов представлена гибридная керамика, сочетающая черты нарвской и сперрингс. Этот пример, однако, остается до настоящего времени единственным.

Каменная индустрия памятников как с керамикой типа сперрингс, так и с нарвской керамикой, ориентирована практически исключительно на использование локального сырья, что обусловило облик каменного инвентаря и его локальные различия внутри ареала распространения обоих типов керамики. В ареале распространения керамики сперрингс в Финляндии, на Карельском перешейке, в Северном Приладожье основным сырьем для изготовления каменного инвентаря являлся кварц, в Западном и Северном Прионежье достаточно широко использовался сланец, в Южном Приладожье и в Восточном Прионежье - кремень. Разнообразие в использовании ло- 
кального сырья отмечается и для ареала распространения нарвской культуры - на территории Эстонии это преимущественно кварц, хотя использовался и местный низкокачественный кремень, и иные породы [22].

Локальные различия, прежде всего связанные с использованием локального каменного сырья, отмечаются уже для позднего мезолита [15]. Сформировавшаяся в позднем мезолите система жизнеобеспечения, основанная на комбинированном использовании лесных ресурсов и ресурсов побережья, сохраняется и развивается и после распространения керамики. Сохраняется в целом и система расселения. Доля изделий из импортных материалов также мала или даже снижается по сравнению с поздним мезолитом. То есть носители раннекерамических традиций в регионе продолжали линию культурного развития, сформировавшуюся в предшествующий период.

Высокопродуктивная присваивающая система жизнеобеспечения, комбинирующая эксплуатацию нескольких экологических ниш, ориентированность каменной индустрии на максимальное использование узколокального сырья, отсутствие свидетельств устойчивых связей с удаленными территориями, возможно, свидетельствуют о формировании определенных границ относительно небольших территорий, контролируемых отдельными коллективами.

Если убрать из рассмотрения керамику и учесть различия материальной культуры, связанные с использованием локального сырья, в целом облик культуры населения региона Финского залива в позднем мезолите - раннем неолите достаточно схож. Иной отчетливый культурный маркер, разделяющий два ареала, помимо керамики, назвать затруднительно. Следует, правда, учитывать тафономию археологических материалов каменного века в регионе, обусловившую практически полное отсутствие сохранившихся артефактов из органических материалов.

Тем не менее «одномоментное» в археологическом смысле появление в регионе во второй половине 6 тыс. до н.э. двух ареалов резко отличных типов керамики предполагает формирование в предшествующее время двух культурных ареалов, население которых с освоением изготовления посуды из глины проявило свое отличие друг от друга двумя керамическими традициями. Таким образом, возникновение границы между двумя культурными ареалами в восточной части Финского залива могло произойти, согласно археологическим данным, в период позднего мезолита, в 7 - середине 6 тыс. до н.э.

Согласно результатам палеогенетических исследований [33], можно предполагать около рубежа 7 и 6 тыс. до н.э. масштабную миграцию населения из Центральной/Восточной Сибири в Восточную Европу. Граница распространения характеризующих эту миграцию гаплогрупп помещается между р. Волгой и Уралом.

Следует указать и на соответствие предполагаемого времени возникновения границы культурных ареалов так называемому «климатическому событию 8200 кал. л.н.» [34; 35], хотя обоснованно связать эти события на настоящий момент не представляется возможным.

Интересными представляются в этом отношении и предварительные результаты изучения артефактов из зубов животных из позднемезолитического Оленеостровского могильника на Южном Оленьем ост- рове (Онежское озеро), проводимого группой исследователей под руководством К. Маннермаа [36]. Сравнение технологии изготовления подвесок из зубов лося на Оленеостровском могильнике в Онежском озере и других аналогичных материалов соответствующего времени из Восточной Европы позволило предположить для периода позднего мезолита наличие в лесной полосе Восточной Европы двух технологических традиций изготовления данной категории костяного инвентаря, представленных в двух географически различных ареалах. Источниковедческие возможности данного исследования для относительно точного определения границ этих ареалов ограничены, но предположительно граница эта должна проходить между Онежским озером и Прибалтикой.

Обе раннекерамические традиции - сперрингс и нарвская - просуществовали в регионе Финского залива приблизительно до рубежа 5 и 4 тыс. до н.э., когда на смену им приходит распространившаяся по всему региону ТГК. Эта керамика существенно отличается от предшествовавших ей традиций нарвской и сперрингс. Она плотная, хорошо обожженная, имеет примесь песка и мелкой дресвы. Это также крупные круглодонные непрофилированные сосуды, но срез венчика здесь, как правило, скошен внутрь, имеет утолщение и украшен гребенчатым штампом. Орнаментирована различными сочетаниями оттисков гребенчатого штампа и ямок, образующими горизонтальные зоны или геометрические узоры (рис. 4). Внутри ареала распространения ТГК выделяется значительное количество локальных традиций [37]. При этом в сравнении как с предшествующими, так и с пришедшими ей на смену керамическими традициями, а также с керамическими традициями, представленными одновременно с ней на других территориях, ТГК выглядит весьма стандартизированной технологически, морфологически и орнаментально в пределах всего ареала распространения.

Смена керамических традиций сопровождалась существенными изменениями в других сферах материальной культуры, системе расселения и коммуникаций. В материалах археологических памятников появляется значительное количество изделий из импортного (по-видимому, преимущественно верхневолжского) кремня [38]. При том, в отличие от материалов периода раннего мезолита, представлены не только конечные изделия, но и заготовки, технологические сколы и отходы производства. Это позволяет заключить, что технология площадочного расщепления, в частности технология изготовления бифасиальных наконечников, становится значимой составляющей каменной индустрии. Обилие изделий из импортного кремня, попадающего на рассматриваемую территорию в виде заготовок и пренуклеусов, предполагает существование устойчивых каналов его поступления. Существенно возрастает в коллекциях процент изделий из других импортных материалов - янтаря, сланца (напр.: [39]). Все это свидетельствует о формировании в период существования традиции ТГК новой развитой системы внутрии межрегиональных коммуникаций. В это время появляются поселения с углубленными в землю жилищами [40]. Система обеспечения продолжает основываться на эксплуатации того же комплекса ресурсов, что и в предыдущее время, но появляются первые возможные свидетельства культивации растений. 

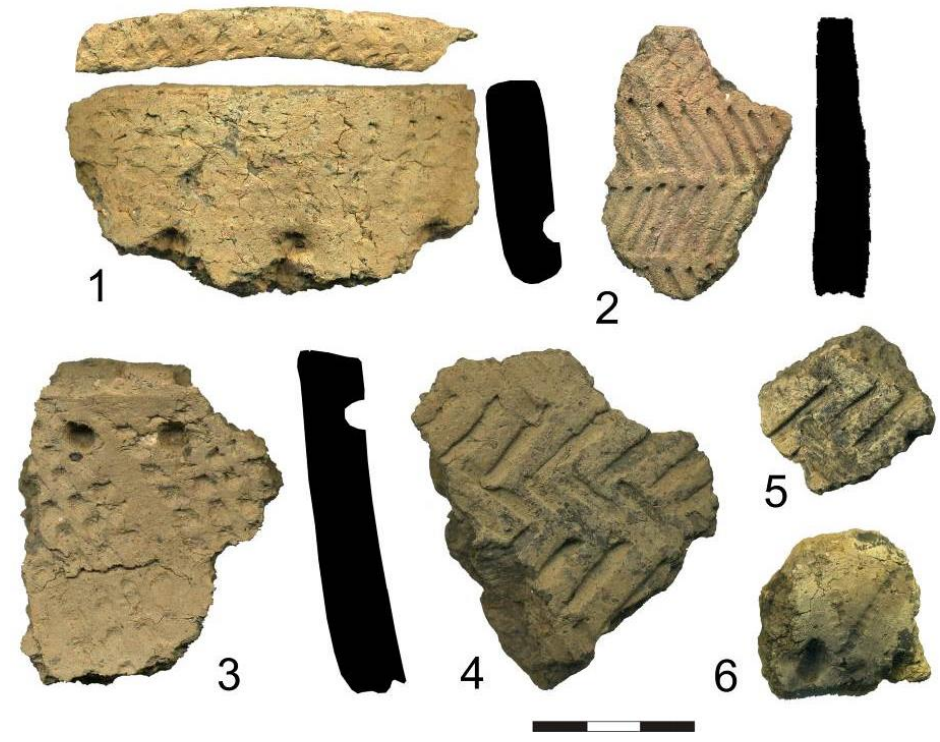

Рисунок 2 - Керамика типа сперрингс.

1 - Холмогорское 1, 2- Комсомольское 3, 3- Озерное-3, 4- Каменка 1, 5- Тарховка, 6- Силино

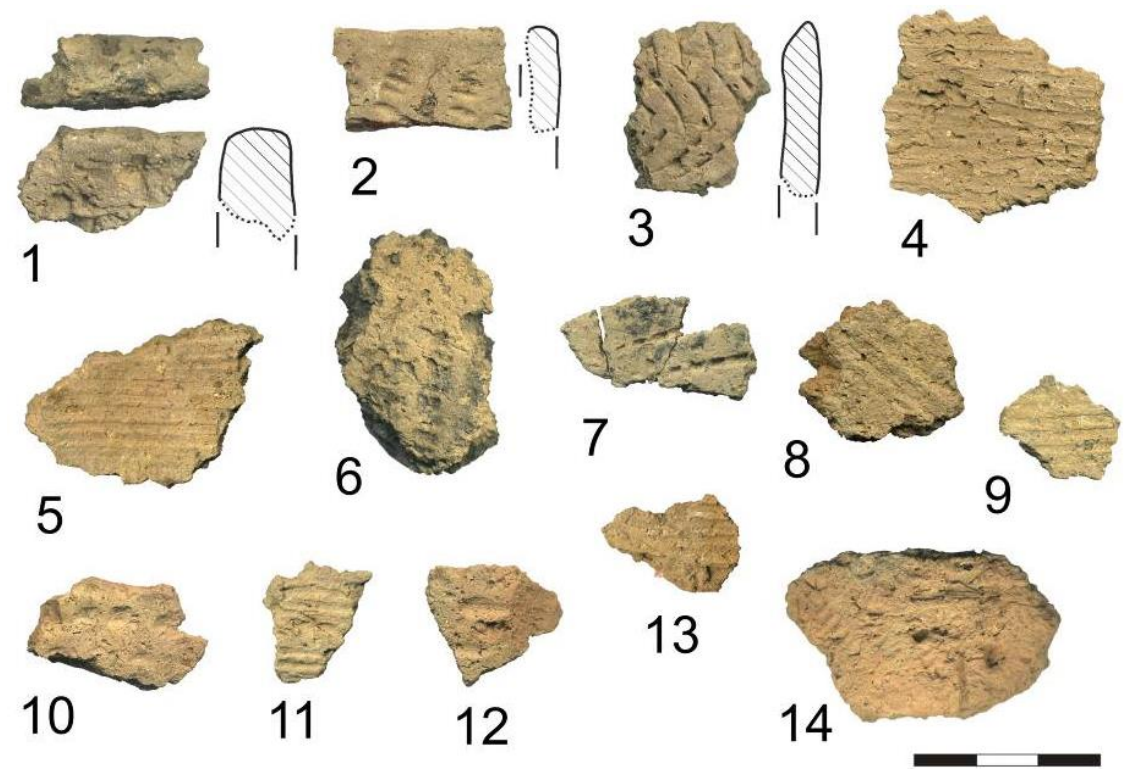

Рисунок 3 - Нарвская керамика. Куземкино 6

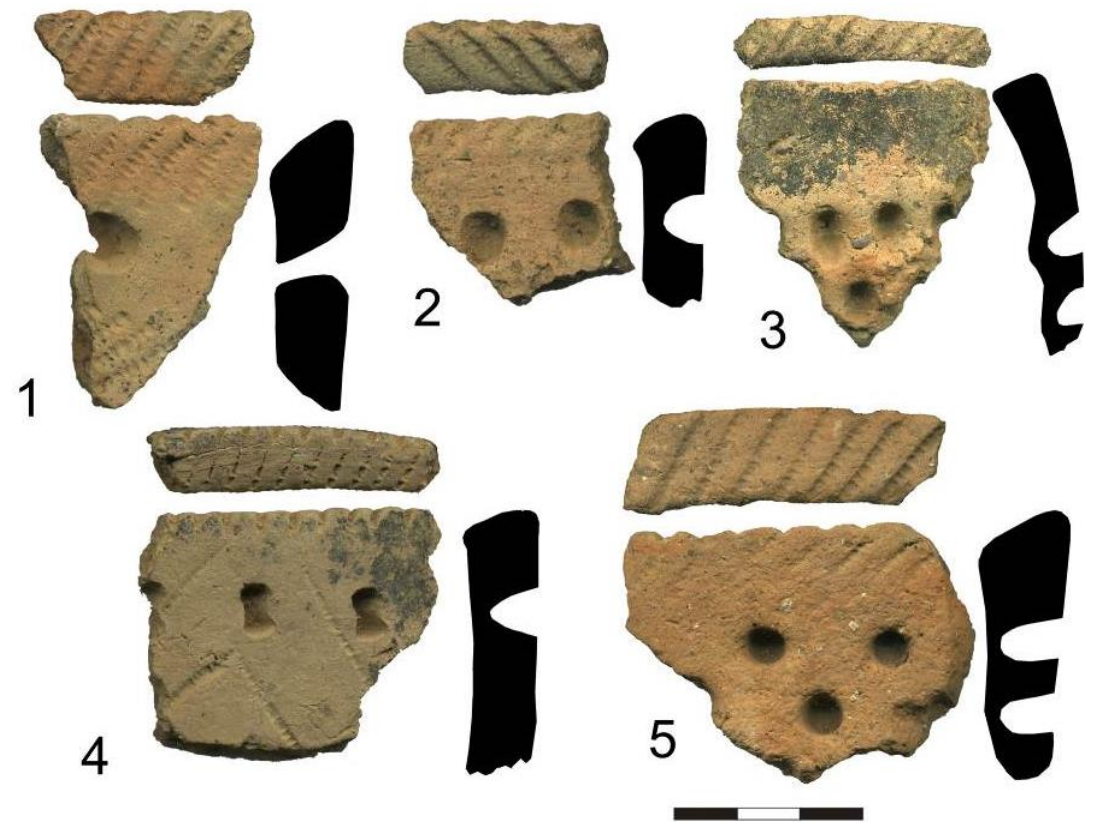

Рисунок 4 - Типичная гребенчато-ямочная керамика.

1- Куровицы 2; 2- Извоз 3; 3-Силино; 4-Озерное 3; 5- Каннельярви 1 
ТГК была распространена в регионе Финского залива до конца 4 тыс. до н.э. После этого традиция распадается на несколько ареалов. Представленные в этих ареалах керамические группы наследуют ряд черт ТГК, но при этом имеют выраженную субрегиональную специфику. Восточная часть региона Финского залива в позднем неолите - эпоху раннего ме- талла (конец 4-3 тыс. до н.э.) является периферийной зоной для ареалов распространения нескольких типов керамики. Граница между ареалами с течением времени могла несколько сдвигаться, но она всегда отделяла северные районы Карельского перешейка от юго-запада Ленинградской области и южного Приладожья (рис. 5).

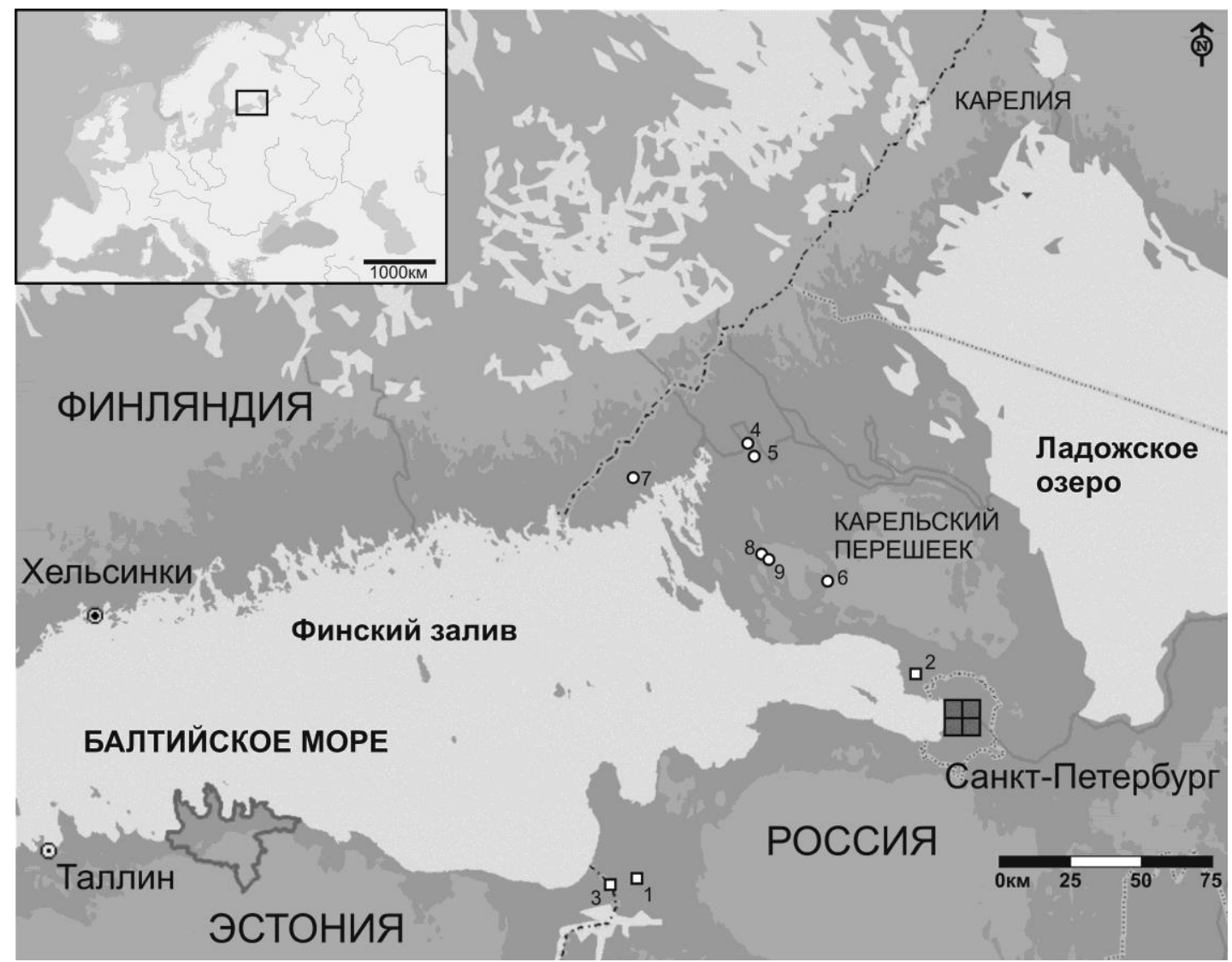

Рисунок 5 - Карта опорных комплексов с поздненеолитической керамикой в восточной части региона Финского залива. Памятники с поздней гребенчато-ямочной керамикой:

1 - Извоз-3; 2- Тарховка; 3- Рийгикюла II. Памятники с керамикой типа ускела: 4- Гвардейское 1; 5- Озерное 3; 6- Каннельярви 1; 7- Холмогорское 2; 8- Каменка 1; 9- Камышевка

Керамика типа ускела (Ка III:1 по А. ЕвропеусуЭуряпяа [41]) характеризуется пористой структурой черепков со следами неидентифицированной примеси (известняка?), разреженной орнаментацией с преобладанием ямок в сочетании с короткими отпечатками гребенчатого штампа и гладкой, без расчесов, поверхностью. Эта керамика на российской территории зафиксирована только на памятниках в центральных и северных районах Карельского перешейка, южнее она не распространяется (рис. 6: 1-4).

Керамика с примесью асбеста встречается исключительно на северном берегу Финского залива и в южном Приладожье и не встречается южнее p. Невы. Асбестовую керамику можно разделить на два типа в соответствии с типологией керамики, предложенной для территории Финляндии: Киерикки и Пёлья. Основным критерием отнесения сосудов к типу Пёлья является наличие Г-образного загнутого внутрь венчика [42]. Поверхность части сосудов обработана интенсивными расчесами гребенчатым штампом или пучком травы, встречается и орнаментация, состоящая из отпечатков «веревочки-напалочке» или мелких ямок-точек [43; 44]. Сосуды типа Киерикки характеризуют округлое донце; прямой или слегка утолщенный венчик. Сосуды керами- ки типа Киерикки орнаментированы тонким длинным гребенчатым штампом, ямочными вдавлениями или прочерченными линиями. При этом сосуды, по большей части, орнаментированы полностью - в том числе по краю венчика и по внутренней поверхности стенок [45].

Для эстонской поздней гребенчато-ямочной керамики группы 1 [46] характерна примесь дробленой раковины, преимущественно срезанные внутрь и орнаментированные отпечатками гребенчатого штампа венчики и орнаментация, состоящая в основном из чередующихся рядов ямок и отпечатков гребенки (рис. 6: 5-6). Такая керамика представлена на южном побережье Финского залива и на стоянках на оз. Сестрорецкий Разлив в южной части Карельского перешейка. Далее на север она не распространяется.

При наличии в период позднего неолита - эпоху раннего металла в регионе Финского залива нескольких вполне выраженных и хорошо различающихся между собой по целому набору признаков типов керамики, ареалы которых имеют достаточно отчетливые границы, сохраняется развитая система внутрии межрегиональных связей, сформировавшаяся в предыдущий период. Об этом свидетельствуют представленные в археологических материалах мно- 
гочисленные импортные изделия и изделия из импортных материалов (кремень, янтарь, онежский метатуф и т.д.), указывающие на разнонаправленность и устойчивость удаленных контактов. Системы расселения и жизнеобеспечения в целом продолжают прежнюю линию развития. Таким образом, снова из доступных археологических источников основным признаком субрегиональной и локальной культурной специфики является керамика.

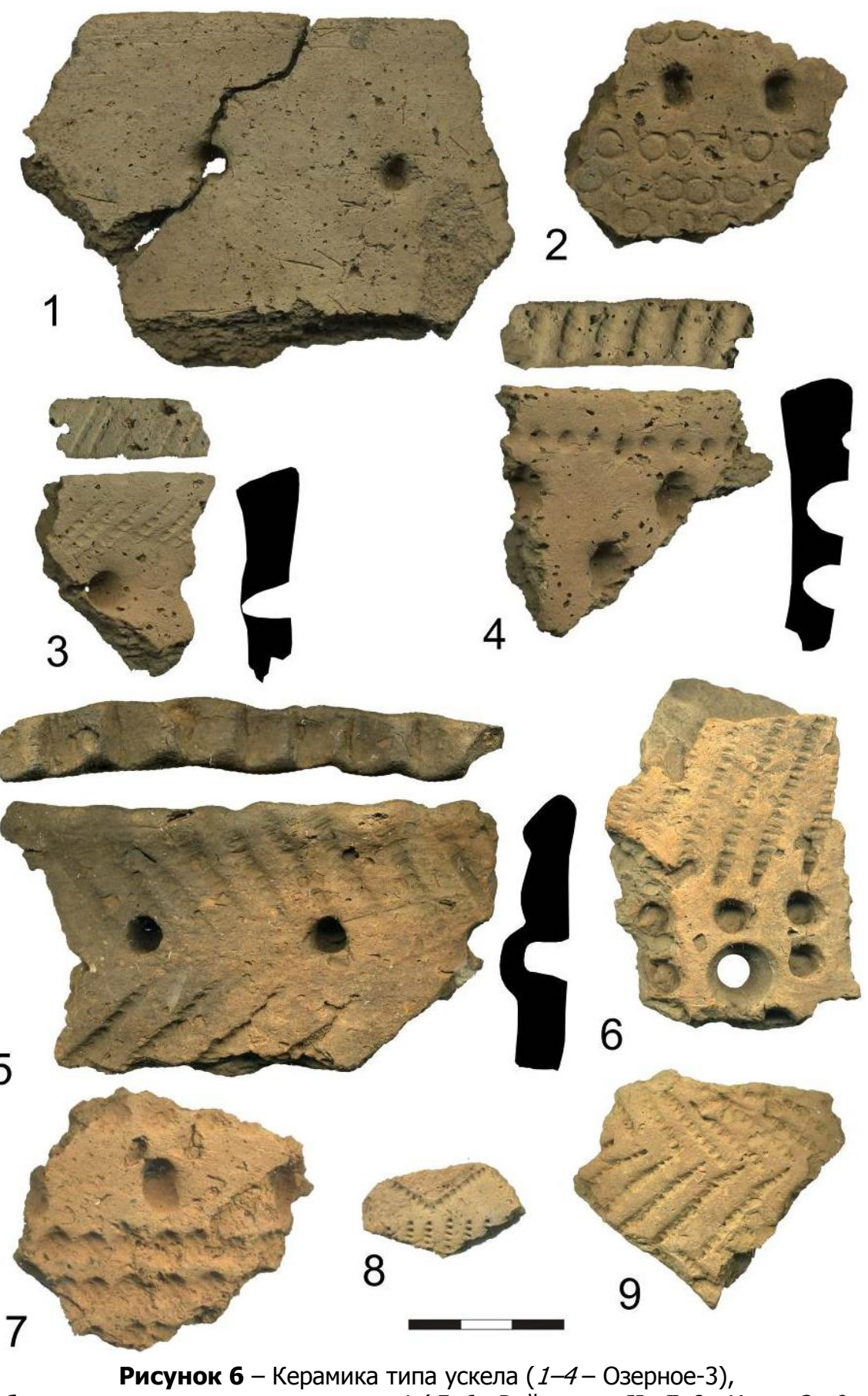

поздняя гребенчато-ямочная керамика группы 1 (5-6- Рийгикюла II; 7-8- Извоз-3; 9- Тарховка)

В этой связи весьма интересны выводы о наличии проходившей в конце неолита через восточную часть региона Финского залива границы ареалов распространения разных традиций искусства малых форм [47].

Имеющиеся археологические данные свидетельствуют о существовании в восточной части региона Финского залива границы культурных ареалов вплоть до времени распространения культуры шнуровой керамики на рубеже 4 и 3 тыс. до н.э., связанного с массовым проникновением в регион нового населения [48].

Столь долговременная устойчивость границы ареалов распространения разных типов археологиче- ского материала, причем тех категорий материала, которые относятся к наиболее выразительными в системе визуальной идентификации «своих» и «чужих», может свидетельствовать о существовании в регионе на протяжении позднего мезолита и неолита двух крупных групп населения с определенными границами расселения. Эту же стабильность границы между группами, появившейся до появления ТГК и вновь проявившейся при распаде этой традиции, можно рассматривать как вероятное свидетельство того, что распространение культуры типичной гребенчато-ямочной керамики (сколь бы явственно эта археологическая культура ни отличалась от предше- 
ствовавших ей) не обязательно было связано со сменой населения в регионе. Интересно в связи с этим предположение о том, что феномен ТГК являлся реакцией населявших регион коллективов на распространение в Европе культуры линейно-ленточной керамики и воронковидных кубков [49].

Существование устойчивых границ культурных ареалов отмечалось для других частей Балтийского региона, их тысячелетняя стабильность связывается с географическими факторами [50]. Выделить географические факторы, которые могли обусловить в восточной части региона Финского залива границу между древними человеческими общностями, на настоящий момент затруднительно. Можно предположить, что условная граница ареалов совпадает с границей разных ландшафтных зон - северной, где береговая линия образована шхерами и архипелагами, и южной, где береговая линия состоит из кос и лагун. Граница между двумя частями региона могла несколько меняться, но она всегда отделяет северные районы Карельского перешейка от юго-запада Ленинградской области. Впрочем, наблюдаемая граница уходит на значительное расстояние от побережья. Задачей будущих исследований является выявление факторов, обусловивших возникновение этого феномена, и получение новых данных для его интерпретации.

\section{СПИСОК ЛИТЕРАТУРЫ:}

1. Дьяченко В.И. Охотники высоких широт долганы и северные якуты. СПб.: Европейский Дом, 2005. 272 c.

2. Клейн Л.С. Археологические источники. Л.: Изд. ЛГУ, 1978. 120 с.

3. Heyd V., Kossinna's Smile // Antiquity, 2017, Vol. 91. № 356. P. 348-359.

4. Tallavaara M., Manninen M.A., Pesonen P., Hertell E. Radiocarbon dates and postglacial colonisation dynamics in eastern Fennoscandia // Lateglacial and Postglacial Pioneers in Northern Europe / F. Riede, M. Tallavaara (Eds.) British Archaeological Reports, International Series S2599. 2014. P. 161-175.

5. Jussila T., Kriiska A., Rostedt T. The Mesolithic settlement in NE Savo, Finland. And the earliest settlement in the eastern Baltic sea // Acta Archaeologica. 2007, 78 (2). P. 143-162.

6. Kriiska A., Lisitsyn S., Gerasimov D.V. Initial settlement of the Gulf of Finland region (the Baltic Sea) // Final programme and abstracts: the 8th International Conference on the Mesolithic in Europe; Santander, Spain, 13th-17th Sept., 2010. / Arias P., Cuerto M. (Eds.). Instituto International de Investigationes Prehistoricas de Cantabria. 2010. Р. 36.

7. Герасимов Д.В., Крийска А., Лисицын С.Н. Освоение побережья Финского залива Балтийского моря в каменном веке // Материалы III Северного археологического конгресса. Екатеринбург. ХантыМансийск: ИздатНаукСервис, 2010. С. 28-53.

8. Жилин М.Г. О связях населения Прибалтики и Верхнего Поволжья в раннем мезолите // Тверской археологический сборник. 2001. Вып. 4, Т. І. С. 72-79.

9. Zhilin M.G. Flint raw material from the Upper Volga basin and its use in the Final Palaeolithic-Neolithic // Man and Flint. Proceedings of the VIIth International Flint Symposium Warszawa - Ostrowiec Święto- krzyski September 1995 / R. Schild, Z. Sulgostowska (Eds.). Warszawa: Institute of Archaeology and Ethnology Polish Academy of Sciences. 1997. P. 331-333.

10. Жилин М.Г., Савченко С.Н. Костяное вооружение как индикатор связей в мезолите лесной зоны Восточной Европы и Зауралья // Культурные процессы в циркумбалтийском пространстве в раннем и среднем голоцене: докл. междунар. науч. конф., посвящ. 70-летию со дня рождения В.И. Тимофеева. СПб.: МАЭ РАН, 2017. С. 140-143.

11. Zhilin M.G., Early Mesolithic communication networks in the East European forest zone // Mesolithic on the move. Papers presented at the Sixth International Conference on the Mesolithic in Europe, Stockholm 2000. Oxford: Oxbow Books. 2003. P. 688-693.

12. Takala $H$. The flint collection from the Ristola site in Lahti and the cultural contacts of the earliest Postclacial settlement of southern Finland // Mesolithic Horizons. Papers presented at the Seventh International Conference on the Mesolithic in Europe, Belfast. 2005. Oxford: Oxbow Books. 2009. P. 31-37.

13. Jussila T., Kriiska A., Rosedt T. Saarenoja 2 - An Early Mesolithic Site in South-Eastern Finland: Preliminary Results and Interpretations of Studies Conducted in 2000 and 2008-10 // Fennoscandia Archaeologica. 2012. XXIX. P. 3-27.

14. Крийска А. Мезолит Эстонии // Тверской археологический сборник. 2009. Вып. 7. Тверь: Триада, С. 32-38.

15. Крийска А., Герасимов Д.В. Период позднего мезолита в восточной части Балтийского моря: формирование берегового расселения от Рижского до Выборгского залива // От Балтики до Урала: изыскания по археологии каменного века. Сыктывкар, 2014. C. 5-36.

16. Seitsonen O., Seitsonen S., Broderick L.G., Gerasimov D. Burnt bones by Europe's largest lake: Zooarchaeology of the Stone Age and Early Metal period hunter-gatherers at Lake Ladoga, NW Russia // Journal of Archaeological Science: Reports 2017, 11. P. 131-146.

17. Kriiska A. Settlements of coastal Estonia and maritime hunter-gatherer economy // Lietuvos archeologija 2000, 19. P. 153-166.

18. Крийска А. Приморская адаптация и заселение Западно-Эстонских островов Балтийского моря в каменном веке // Проблемы биологической и культурной адаптации человеческих популяций. СПб.: Наука, 2008. С. 98-118.

19. Núñez M. On Subneolithic Pottery and its Adoption in Late Mesolithic Finland // Fennoscandia Archaeologica. 1990, VII. P. 27-52.

20. Герасимов Д.В., Крийска А., Лисицын С.Н. Памятники каменного века юго-восточного побережья Финского залива: хронология и геоморфология // Краткие сообщения Института археологии РАН. 2012. Вып. 227. С. 241-247.

21. Piezonka H. Stone Age Hhunter-Gatherer Ceramics of North-Eastern Europe: New Insights into the Dispersal of an Essential Innovation // Documenta Praehistorica. 2012. XXXIX. C. 23-51.

22. Kriiska A., Oras E., Lõugas L., Meadows J., Lucquin A., Craig O.E. Late mesolithic Narva stage in Estonia: pottery, settlement types and chronology // Estonian Journal of Archaeology. 2017. Vol. 21, is. 1. P. 52-86. 
23. Piezonka H. Mesolithic - Sub-Neolithic - Neolithic: The problem of defining neolithization between East and West // Культурные процессы в циркумбалтийском пространстве в раннем и среднем голоцене: докл. междунар. науч. конф., посвящ. 70-летию со дня рождения В.И. Тимофеева. СПб.: МАЭ РАН, 2017. C. $97-103$.

24. German K. Early Hunter-Gatherer Ceramics in Karelia // Ceramics Before Farming: The Dispersal of Pottery among Prehistoric Eurasian Hunter-Gatherers. Left Coast Press / Jordan P. Zvelebil M. (eds),. Walnut Creek. 2009. P. 255-280

25. Nordqvist Mökkönen New radiocarbon dates for early pottery in North-Eastern Europe // Традиции и инновации в изучении древнейшей керамики: мат-лы междунар. науч. конф., 24-27 мая. ИИМК РАН. СПб., 2016. С. 204-214.

26. Pesonen P., Oinonen M., Carpelan C., Onkamo P. Early Subneolithic ceramic sequences in Eastern Fennoscandia - Bayesian approach. Radiocarbon. 2012. 54 (3-4). P. 661-676.

27. Piezonka H. Older than the farmers' pots? Hunter-gatherer ceramics east of the Baltic Sea // J. Kabaciński, S. Hartz, D.C.M. Raemaekers, T. Terberger (Eds.). The Dąbki Site in Pomerania and the Neolithisation of the North European Lowlands (C. 5000-3000 calBC). Marie Leidorf, Rahden. 2015. P. 557-574.

28. Seitsonen O., Nordquist K., Gerasimov D.V., Lisitsyn S.N. «The good, the bad, the weird»: Stone Age and Early Metal Period radiocarbon dates and chronology from the Karelian Isthmus, North-West Russia // Geochronometria. 2012. Vol. 39, № 2, P. 101-121.

29. Чернявский М.М. Памятники нарвской культуры на территории Беларуси: состояние исследования и перспективы // Культурные процессы в циркумбалтийском пространстве в раннем и среднем голоцене: докл. междунар. науч. конф., посвящ. 70летию со дня рождения В.И. Тимофеева. СПб.: МАЭ PAH, 2017. C. 247-251.

30. Rosentau A., Muru M., Kriiska A., Subetto D., Vassiljev J., Hang T., Gerasimov D., Nordqvist K., Ludikova A., Lõugas L., Raig H., Kihno K., Aunap R., Letyka, Nikolay. Stone Age settlement and Holocene shore displacement in the Narva-Luga Klint Bay area, eastern Gulf of Finland // Boreas. 2013. 42 (4). P. 912-931.

31. Kriiska A. The Neolithic pottery manufacturing technique of the lower course of the Narva river Coastal Estonia. Recent Advances in Environmental and Cultural History. PACT 51. Rixensart 1996. P. 373-384.

32. Тимофеев В.И. Памятники мезолита и неолита региона Санкт-Петербурга и их место в системе культур каменного века Балтийского региона // Древности Северо-Запада. СПб. 1993. С. 8-34.

33. Der Sarkissian C., Balanovsky O., Brandt G., Khartanovich V., Buzhilova A. et al. Ancient DNA Reveals Prehistoric Gene-Flow from Siberia in the Complex Human Population History of North East Europe // PLoS Genet. 2013. 9 (2).

34. Lewis C.F.M., Miller A.A.L., Levac E., Piper D.J.W., Sonnichsen G.V. Lake Agassiz outburst age and routing by Labrador Current and the $8.2 \mathrm{cal}$ ka cold event. Quaternary International 260. 2012. P. 83-97.

35. Törnqvist T.E., Hijma M.P. Links between early Holocene ice-sheet decay, sea-level rise and abrupt climate change. Nature Geoscience. 2012. V. 5, P. 601-606.
36. Mannermaa K., Girya E.Yu., Gerasimov D.V. Alteration techniques of elk (Alces alces) and bear (Ursus arctos) tooth pendants at the Late Mesolithic cemetery on Yuzhniy Oleniy Ostrov, the Onega Lake - indicators of cultural and social homogeneity? // Культурные процессы в циркумбалтийском пространстве в раннем и среднем голоцене: докл. междунар. науч. конф., посвящ. 70-летию со дня рождения В.И. Тимофеева. СПб.: МАЭ РАН, 2017. С. 152-157.

37. Нордквист К., Мёккёнен Т. Переосмысление типичной гребенчатой керамики по А. Эйряпя // Древние культуры Восточной Европы: эталонные памятники и опорные комплексы в контексте современных археологических исследований. Замятнинский сборник. Вып. 4 СПб.: МАЭ РАН, 2015. С. 207-217.

38. Галибин В.А., Тимофеев В.И. Новый подход к разработке проблемы выявления источников кремневого сырья для культур каменного века Восточной Прибалтики // Археологические вести. 1993. Вып. 2. СПб. С. 46-53.

39. Zhulnikov A. Exchange of Amber in Northern Europe in the III Millennium BC as a Factor of Social Interactions // Estonian Journal of Archaeology. 2008. 12/1. P. 3-15.

40. Mökkönen T. Studies on Stone Age housepits in Fennoscandia (4000-2000 CAL BC). Changes in ground plan, site location, and degree of sedentism. Helsinki, Unigrafia. 2011. 86 p.

41. Europaeus-Äyräpää A., 1930. Die Relative Chronologie der Steinzeitlichen Keramik in Finland // Acta Archaeologica, 1. P. 165-190.

42. Kriiska A. Narva jõe alamjooksu ala neoliitiline keraamika // Eesti arheoloogia historiograafilisi, teoreetilisi ja kultuuriajaloolisi aspekte. Muinasaja teadus, 3. Tallinn. 1995. P. 54-115.

43. Meinander C.F., Die Kiukaiskultur // Suomen Muinaismuistoyhdstuksen Aikakauskirja, 58. Helsinki: Finska Fornminnesforeningens Tidskrift. 1954. 192 p.

44. Carpelan C. Om asbestkeramikens historia i Fennoskandien // Finskt Museum, 85. Helsinki. 1979. P. 5-25.

45. Pesonen P. Hut floor areas and ceramics - analysis of the excavation area in the Rääkkylä Pörrinmökki settlement site, Eastern Finland // Fennoscandia Archaeologica. 1995. 12. Helsinki. P. 139-151.

46. Siiriäinen A. On the late Stone Age Asbestos Ware Culture of Northern and Eastern Finland // Iskos, 4. Helsinki. 1984. P. 30-36.

47. Кашина Е.А. «Нити взаимодействий» в лесной зоне северо-востока Европы: сходство и различие предметов искусства малых форм (6000-2700 ВС) // Культурные процессы в циркумбалтийском пространстве в раннем и среднем голоцене: докл. междунар. науч. конф., посвящ. 70-летию со дня рождения В.И. Тимофеева. СПб.: МАЭ РАН, 2017. С. 152-157.

48. Крийска А., Нордквист К., Герасимов Д.В. Санделл С. Новые исследования памятников со шнуровой керамикой в Нарвско-Лужском междуречье, в пограничье России и Эстонии // Тверской археологический сборник. Вып. 10, Т. 1. Тверь. 2015. С. 195-203.

49. Нордквист К., Крийска А., Герасимов Д.В. Социальная реорганизация населения каменного века в восточной части Балтийского моря в 4 тыс. до н.э.: структура расселения, стратегия жизнеобеспечения и система коммуникаций // IV Северный археологический конгресс: доклады. 19-23 октября 2015, г. Хан- 
ты-Мансийск / отв. ред. Н.М. Чаиркина; Правительство ХМАО - Югры; Ин-т истории и археологии УрО РАН; Уральский федеральный университет имени первого Президента России Б.Н. Ельцина; Инт археологии и этнографии СО РАН; Ин-т археологии РАН. Екатеринбург, 2015. С. 132-151.

50. Knutsson K., Knutsson H. The structure of the pioneer settlement of Scandinavia. The origin of long lived social territories // Культурные процессы в циркумбалтийском пространстве в раннем и среднем голоцене: докл. междунар. науч. конф., посвящ. 70летию со дня рождения В.И. Тимофеева. СПб.: МАЭ PAH, 2017. C. 135-139.
Статья подготовлена при поддержке РФФИ, проекты 15-06-05548 «Последние пионеры Европы: формирование социально-культурных общностей в регионе Финского залива в условиях природных изменений раннего - среднего голоцена»; 15-05-08169 «Развитие береговых морфосистем юго-восточной части Финского залива в ходе дегляциации и трансгрессивно-регрессивных колебаний уровня послеледниковых водоемов».

Работа М.А. Холкиной по картографированию ареалов распространения керамики была выполнена при поддержке РНФ проект 17-77-20041.

\title{
FORMATION OF SOCIAL-CULTURAL UNITS IN THE GULF OF FINLAND REGION IN CHANGING EARLY AND MIDDLE HOLOCENE ENVIRONMENT
}

(C) 2017

\begin{abstract}
Gerasimov Dmitriy Vladimirovitch, candidate of historical sciences, researcher of Archaeology Department Peter the Great Museum of Anthropology and Ethnography (Kunstkamera) of Russian Academy of Sciences
\end{abstract} (Saint Petersburg, Russian Federation)

Kholkina Margarita Alekseevna, researcher

Research center «Actual Archaeology» (Saint Petersburg, Russian Federation)

\begin{abstract}
Stone Age archaeological material from the eastern part of the Gulf of Finland region are evident of presence here a stable border between cultural areas from the Late Mesolithic till the end of Neolithic. Differences between those areas are mostly become apparent in the certain categories of archaeological finds - first of all in pottery (Sperrings, Narva and Late Neolithic types) as well as in decorations and mobile art. The border survives through millennia though sufficient cultural transformations in material culture developed during that time in the region. The border could arise in the Late Mesolithic, in the 7th - middle of the 6th ca. BC. Hypothetically its arising could be related to appearance of new people in the region, and possibly with the «8200 cal. BP climatic event». The border is visible in archaeological material till the mass migration of the Corded Ware culture people in the region about the turn of 4th and $3 \mathrm{~d}$ ca. BC. The phenomenon of the Typical Combed Ware culture that existed in the region from the end of 5th till the second half of the 4th ca. BC probably was not related to the new people coming but can reflect integration of the aborigine population in response to some outer (socio-cultural?) factors.

Keywords: Gulf of Finland; Ladoga Lake region; archaeology; archaeological culture; migrations; Late Mesolithic; Neolithic; pottery; Sperrings Ware; Narva Ware; Typical Comb Ware; Uskela Ware; Asbestos Ware; Late Comb Ware; Corded Ware; social networks; cultural areas; border; social-cultural units.
\end{abstract}

\section{КОМПЛЕКСНЫЕ ИССЛЕДОВАНИЯ ТЕРРИТОРИИ БЕРЕЗОВОСЛОБОДСКОГО АРХЕОЛОГИЧЕСКОГО КОМПЛЕКСА НА НИЖНЕЙ СУХОНЕ} (C) 2017

Иванищева Марина Викторовна, научный сотрудник

Учреждение культуры «Вологдареставрация» (2. Вологда, Российская Федераџия)

Кулькова Марианна Алексеевна, кандидат геолого-минералогических наук, доцент кафедры географии Российский государственный педагогический университет имени А.И. Герцена

(2. Санкт-Петербург, Российская Федераичи)

Иванищева Елизавета Александровна, кандидат биологических наук, доцент кафедры географии Вологодский государственный университет (г. Вологда, Российская Федерация)

Аннотация. В статье представлены результаты комплексных исследований участка компактного расположения археологических памятников, включающих разновременные стоянки и поселения на ключевом участке Березовая Слободка в бассейне Нижней Сухоны (восточная часть Вологодской области). В ходе ландшафтных исследований уточнена геоморфология участка, определены приуроченность разновременных стоянок к различным элементам рельефа и приоритетные факторы предпочтений древнего расселения. Ландшафтные исследования зоны ближнего жизнеобеспечения древнего населения показали, что относительно безопасное размещение и обеспечение разнообразными хозяйственными угодьями и природными ресурсами древнего населения определялось сложностью и высоким разнообразием ландшафтной структуры, сформировавшейся на стыке долинно-склоновых комплексов Сухоны и впадающей в Сухону Уфтюги. Геохимические исследования аллювиально-почвенных отложений на многослойном поселении Березовая Слободка II-III, вмещающих культурные слои от эпохи финального палеолита до раннего железного века, позволили охарактеризовать климатические условия формирования культурных горизонтов, оценить периоды древнего антропогенного влияния и сделать выводы о характере водоема и периодах формирования речных 